\title{
Recursive Cointegration of Energy and Stock Prices in Indonesia
}

\author{
Nur Setyowati
}

\begin{abstract}
The purpose of this study is to investigate the time-varying behavior and the dynamic linkages of Indonesian exchange rate, and stock, oil, and natural gas prices over the period from 2005 to 2015 . To capture the dynamics of long-run relationships, we use the Gregory and Hansen (1996) cointegration test with structural break and a recursive cointegration test to examine the time-varying nature of convergence here. The main findings are as follows. First, the result of the Gregory and Hansen (1996) test shows that the main structural break occurred in the long-run cointegration around 2008 and 2009 and was caused by the 2008-2009 global financial crisis. Second, the results of recursive cointegration present cointegration among the variables after 2009. Third and finally, the results of recursive cointegration's coefficients display that increasing oil prices produce a drop in Indonesian stock prices, while rising gas price will bring about higher stock price.
\end{abstract}

Index Terms-Stock price, oil price, natural gas price, recursive cointegration.

\section{INTRODUCTION}

The relative fundamental theory indicates that energy commodities influence liquidity in financial markets by affecting basic macroeconomic variables. The relationship between energy prices and stock prices is an interesting and important topic for investors, as it pertains to opportunities for international portfolio diversification. Stock market returns or prices are affected by oil price shock through expected earnings [1]. Many papers examine the relationship between stock and oil prices, but the relative literature does not show any consistent conclusion. Some studies confirm the existence of a relationship between oil prices and stock markets [2]-[4], while others present opposite finding [5]. Most of the past relative papers focus on the impact of oil price changes on the stock markets, but fewer papers have studied the relationship between natural gas and stock prices. To fill this gap, this paper discusses how changes in natural gas prices influence stock prices.

The purpose of this study is to investigate the time-varying behavior and the dynamic linkages between stock, oil, and natural gas prices for the period of 2005 to 2015 in Indonesia. Following the work of [4], we also take the exchange rate as an additional variable in the estimated model of this paper, because it links stock markets and energy commodities via an indirect channel. This research contributes to the literature in three ways as follows.

Manuscript received March 17, 2016; revised July 15, 2016

Nur Setyowati is with the National Kaohsiung University of Applied Sciences, Taiwan (e-mail: setyowati.first@gmail.com).
First, there is no study using a multivariate framework to investigate the relationship among crude oil, natural gas, and Indonesian stock prices. It is important to extend the model from bivariate to multivariate in order to reduce the effect of omitted variable bias and to give a clear view of the Indonesian stock market. Second, this paper uses two different methods, Gregory and Hansen's [6] cointegration test with a structural break and a recursive cointegration test, which have not been used in previous relative research, to capture the dynamics of long-run relationships between stock prices and the two energy prices. According to the results of recursive statistics to estimate the gradual convergence over time, we can confirm whether the degree of integration among Indonesian stock, oil, natural gas prices and the exchange rate is consistent over the sample period, either it decreases or it increases over time. Third, most previous studies on the Indonesian stock market only employ the Jakarta Composite Stock Index (JKSE) and omit the Jakarta Islamic Index (JII) as the measurement for Indonesian stock prices. This paper uses both indices to give a clearer understanding of the Indonesian stock market and to contribute to the literature discussing how this country's stock market reacts to changes in energy prices.

The rest of the paper is organized as follows. Section 2 offers a glance at the background of the study. Section 3 explains the empirical results. Lastly, section 4 provides conclusions of the study.

\section{BACKGROUND AND LITERATURE REVIEW}

\section{A. Background}

Indonesia has become an important part of the global economy. Its economy is the 16th largest in the world based on nominal GDP and 5th largest according to GDP's Purchasing Power Parity as stated by the International Monetary Fund in 2014. Rapid economic growth in the country has led to a rise of its financial sector, especially the local capital market. Its stock market has not only grown in market capitalization, but has also seen an increase in the number of companies and shares listed. The market capitalization of the market has been growth by $209.48 \%$ from 24,839 billion Rupiah in 1992 to 5,228,043 billion Rupiah in 2014. The number of listed companies rose 21 times from 1985 when it opened for the first time to the public, to 506 companies in 2014 [7].

There are two main stock indices to measure the performance and the value of nation's stock market. The first one is the Jakarta Composite Stock Index (JKSE), which is an index of all stocks that trade on the Indonesia Stock Exchange. 
The second one is the Jakarta Islamic Index (JII), which was established in 2002 to act as a benchmark for measuring market activities based on Islamic law. Both indices showed strong growth in the past decade, growing by up to 4 times from 2005 to 2015.

In the Asia-Pacific region, Indonesian oil production is second only to China. Indonesia produced 911,000 barrels per day (b/d) of petroleum and other liquids in 2014, although it is much lower than the highest production of nearly 1.7 million barrels per day (b/d) in 1991. Indonesia's total primary energy consumption grew $43 \%$ between 2003 and 2013. To meet domestic demand, Indonesia had become a net oil importer by 2004 after domestic demand outstripped production, which has been on a general decline since 1991. Indonesia currently buys crude oil and oil products through third-parties or traders and wants direct access to long-term crude oil supply contracts to support its demand and oil consumption [8].

Indonesia's energy consumption has been growing every year. The average energy consumption from 2000 to 2012 increased by $2.9 \%$ per year, thus ranking Indonesia 4 th in energy consumption in Asia and 14th in the world in 2013. In 2011, its total energy consumption hit 6424 quadrillion Btu, with $35.4 \%$ of this energy used by industry, followed by households at 31.5 and transportation at $27 \%$.

Given the facts that stock markets are sensitive to economic conditions [9], changes in energy commodities lead to changes in stock market levels eventually. When commodity prices are low, manufacturing earnings increase and stock price generally soon follow. In contrast, high commodity prices raise production costs, reduce earnings, and bring about a fall in stock prices. One example reported by [10] is the oil price hike from 2004 to 2006 slowing down the global economy, as economies found it hard to assimilate with prices rising at a fast rate. The price hikes from surging oil resulted in higher production costs for firms and thus lower profit margins. In contrast, when crude oil fell to below US\$50 dollar per barrel from US\$110 dollar per barrel (based on the West Texas Intermediate and Brent Crude Benchmark), Indonesia as a net oil importer got more benefits, because cheaper oil prices stimulated economic growth through greater consumption [11].

\section{B. Literature Review}

Enormous researchers study the impacts from oil price on stock markets in developed country. Reference [12] examines the relationship between WTI oil price and US monthly stocks positions, and [13] investigates whether oil price pushes the stock market into bear territory, both found the similar result that oil price has a significant negative effect on stock price. Reference [14] examine long-run relationship between the world price of crude oil and six OECD's stock markets and find that stock market indices respond negatively to increases in the oil price in the long run. Furthermore, [15] using A DCC-GARCH-GJR to explore the time-varying correlation between stock market prices and oil prices for oil-importing and oil-exporting countries, they find that oil prices exercise a negative effect in all stock markets, regardless the origin of the oil price shock. The only exception is the 2008 global financial crisis where the lagged oil prices exhibit a positive correlation with stock markets.
Conversely, [16] discover that the positive relationship between oil prices and equity values and there is often highly significant direct impact of volatility of oil price on share values within the sector while exploring the relationship between oil prices and equity values in the UK. The similar finding is discovered by [17]. Within the framework of a VAR, they find evidence of oil prices Granger causing stock prices, but no evidence of the opposite relationship. The behavior of all stocks examined is very similar; they all respond positively to a shock in crude oil prices on the same day and the day after the shock, with the impact of the shock disappearing thereafter. Applying Granger causality to study the relationship among alternative energy stock prices, technology stock prices, and oil prices, [18] find that technology stock prices and oil prices lead the stock prices of alternative energy companies.

Moreover, [19] study oil price shocks on real stock returns in the U.S. and in 13 European countries. Their results show that oil price shocks could statistically significant influence on real stock returns contemporaneously and/or within the following month in the U.S. and 13 European countries, while in Norway, being an oil exporter there is a significantly positive response to real stock returns to an oil price increase. Reference [5] analyze how three different structural changes of oil price affect stock-market returns by applied a daily data sample of Australia, Canada, France, Germany, Italy, Japan, United Kingdom, and United States. They find that international stock market returns do not respond in a large way to oil market shocks because different oil-market structural shocks can significantly explain the adjustments in stock-market returns but the magnitude of such effects is small. The similar result is shown by [20]. They study the effect of oil prices and the stock returns of oil and gas firms in Central and Eastern European (CEE) countries, and their results display no significant linkage between oil prices and the stock returns over the period from 1998 to 2010. On the other hand, [21] discover that (asymmetric) oil price shocks do influence real stock returns mostly under the extreme performance of stock markets. In general, investors are more pessimistic to bad news when the stock market stays under a worse performance. Reference [22] show that rising oil price will significantly cause the volatility of stock returns and the probability of transition across different time.

In the cases of the oil forecasting power to stock market, [23] discovers that oil prices are important in explaining stock price movements using a multivariate VAR approach. Reference [24] investigate the ability of oil price returns, oil price shocks and oil price volatility to provide predictive information on the state of the US stock market returns and volatility from January 1989 to December 2011 using probit regression. The results suggest that oil price returns and volatility possess the power to forecast the state of the US stock market returns and volatility.

As to the relative literature to study the cases of emerging countries, [2] study the relationship between oil price to and macroeconomic activity in Asian countries. They find that oil price can significantly affect both economic activity and price index although the impact is limited to the short run [3] examine the impact of oil prices on Vietnam's stock prices, and the results confirm that stock prices, oil prices, and 
nominal exchange rates are cointegrated. Besides, [3] indicate that the impact of oil price on stock price is positive, which is caused by some internal and domestic factors on the Vietnamese stock market. Being Different from the results of [3], [25] find that crude oil prices and Asia-Pacific stock market returns are generally weak. Their results also present that the relationship between oil prices and stock returns was positive before the global financial crisis, except in Hong Kong, and it increased significantly in the aftermath of the crisis. Furthermore, [26] investigate the relationship between oil prices and the Chinese stock market at the sector level. Their results indicate that structural breaks exist in the interaction between oil prices and Chinese sectorial stocks, and the real oil price can positively affect sectorial stocks in the long-run.

Several studies have investigated the relationship between Indonesian stock market and oil price. Using LVAR causal model, [27] analyze the relationship between world crude oil prices and Indonesian stock market, and they find that there was a significant dynamical relationship between world crude oil prices and Indonesian composite index, not matter in the long-term or in the short-term. Reference [27] also show that the dynamics of this relationship is positive, which implies that if the world crude oil price rises (falls), then the composite index also rises (falls). Reference [28] also analyze the relationship between commodities (crude oil and gold) and relevant financial variables in Malaysia, Thailand and Indonesia. Their results discover that dynamic correlation between commodities and financial variables exists not only in Indonesia but also in Malaysia and Thailand. Reference [29] study how world oil price changes can influence on the stock market returns in Southeast Asia, including Indonesia, Malaysia, Singapore, Philippines, and Thailand, whose results find that world oil price changes only give significant effects on the Malaysian and Thailand capital market but Indonesian capital market do not be affected by world oil price.

However, there is no study using the multivariate framework to examine the relationship of crude oil price, natural gas price, and Indonesian stock price. For fill this gap, this paper will investigate the time-varying behavior and the dynamic linkages of stock prices and two energy prices, including oil price and natural gas price in Indonesia.

\section{MPIRICAL RESULT}

\section{A. Result of the Unit Root}

The data cover June 2, 2005 to May 29, 2015, and include 2,479 observations. The choice of the sample considers the availability of Indonesian stock market data. Daily data of West Texas Intermediate crude oil prices and Henry Hub Natural Gas Spot Prices are taken from the website of Energy Information Administration (EIA) (www.eia.doe.gov), while rupiah-dollar exchange rate data are taken from International Monetary Fund (IMF) website (www.imf.org). The Indonesian stock market is measured by the Jakarta Islamic Index (JII) and Jakarta Composite Stock Index (JKSE), and both market's data are downloaded from yahoo finance website (finance.yahoo.com).

Before all the data series of crude oil and natural gas prices, the exchange rate, JII, and JKSE are examined for cointegration, all of them are tested for stationarity. Aside from DF-GLS [30] being used, this paper applies the ZA [31] unit root test, allowing for an endogenous structural break. Table I displays the results of the unit root test. The results of the ZA and DF-GLS unit root tests support that all variables follow I(1) processes at the 5\% significant level. Most structural breaks of all variables, when examined by the ZA test, appear around 2008 and 2009, which was the period of global financial crisis that led to significant fluctuations in oil, gas, and stock markets worldwide.

The oil industry experienced dramatic changes in this period, with prices peaking at approximately US\$145 in mid-2008 and then, collapsing by more than $70 \%$ to end at approximately US\$40 per barrel [32]. In accordance with oil prices, JII also saw the worst conditions. From its highest point at 517.814 on February 28, 2008, it dropped to the lowest level of 172.710, on October 28, 2008. Similarly, this also occurred to JKSE, which decreased from the highest level at 2,830.263 on January 9, 2008 to the lowest level at 1111.39 on October 28, 2008.

TABLE I: RESULT OF THE UNIT ROOR TEST

\begin{tabular}{lccccc}
\hline \multicolumn{5}{c}{ ZA } & \multicolumn{2}{c}{ DF-GLS } \\
\hline Model & A & B & C & Without Trend & With Trend \\
\hline \multirow{2}{*}{ Levels } & & & & \\
JII & -3.504199 & -2.550779 & -3.940780 & 0.904185 & -1.61795 \\
& $6 / 24 / 2008$ & $1 / 09 / 2009$ & $6 / 24 / 2008$ & $(-6)$ & $(-6)$ \\
JKSE & -3.066631 & -2.434034 & -2.923941 & 0.724910 & -2.333655 \\
OIL & $3 / 01 / 2010$ & $11 / 21 / 2013$ & $3 / 01 / 2010$ & $(0)$ & $(0)$ \\
& -2.435250 & -2.670573 & -3.133883 & -1.224000 & -1.69171 \\
GAS & $10 / 7 / 2008$ & $11 / 5 / 2013$ & $7 / 29 / 2008$ & $(-1)$ & $(-1)$ \\
& -4.675985 & -3.816770 & -4.750663 & -1.852136 & -3.03114 \\
ER & $6 / 17 / 2008$ & $8 / 17 / 2010$ & $6 / 17 / 2008$ & $(2)$ & $(2)$ \\
& -3.000839 & -2.430169 & -3.049265 & -0.514405 & -0.69158 \\
& $3 / 23 / 2009$ & $7 / 05 / 2011$ & $3 / 23 / 2009$ & $(0)$ & $(0)$ \\
JII & $-28.7122 * * *$ & $-28.6618 * * *$ & $-28.7296 * * *$ & $-33.9355 * * *$ & $-31.2001 * * *$ \\
JKSE & $11 / 23 / 2012$ & $9 / 12 / 2008$ & $11 / 26 / 2012$ & $(-2)$ & $(-3)$ \\
& $-26.9675 * * *$ & $-26.8264 * * *$ & $-27.0034 * * *$ & $-46.6524 * * *$ & $-46.1843 * * *$ \\
OIL & $12 / 12 / 2008$ & $11 / 18 / 2013$ & $8 / 18 / 2008$ & $(0)$ & $(0)$ \\
& $-22.4021 * * *$ & $-22.2362 * * *$ & $-22.4396 * * *$ & $-5.36887 * * *$ & $-6.3184 * * *$
\end{tabular}




\begin{tabular}{cccccc} 
& $1 / 22 / 2009$ & $7 / 15 / 2013$ & $7 / 21 / 2008$ & $(-11)$ & $(-11)$ \\
GAS & $-22.8219^{* * *}$ & $-22.70913 * * *$ & $-22.83110^{* * *}$ & $-40.67830^{* * *}$ & $-41.0012^{* * *}$ \\
& $6 / 13 / 2008$ & $9 / 16 / 2008$ & $6 / 13 / 2008$ & $(1)$ & $(1)$ \\
\multirow{2}{*}{ ER } & $-19.0395 * * *$ & $-18.8417 * * *$ & $-19.0340^{* * *}$ & $-5.33196^{* * *}$ & $-5.28762 * * *$ \\
& $3 / 23 / 2009$ & $9 / 24 / 2009$ & $3 / 23 / 2009$ & $(-7)$ & $(-7)$ \\
\hline
\end{tabular}

Notes: *,**,*** indicate significance at the 10\%,5\%, and 1\% levels, respectively. DF-GLS and ZA are unit root tests proposed by [24] and [25], respectively. The numbers in parentheses are the lag order, being selected on the basis of SC, in the DF-GLS tests. The numbers in brackets of the ZA tests are the estimated structural break dates.

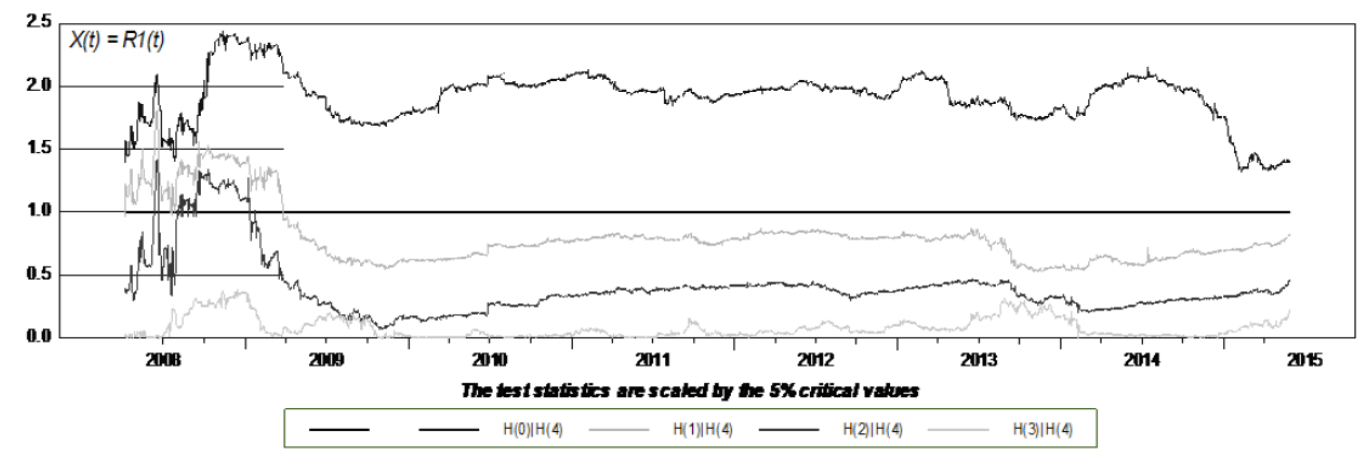

Fig. 1. Recursive trace statistics (JII)

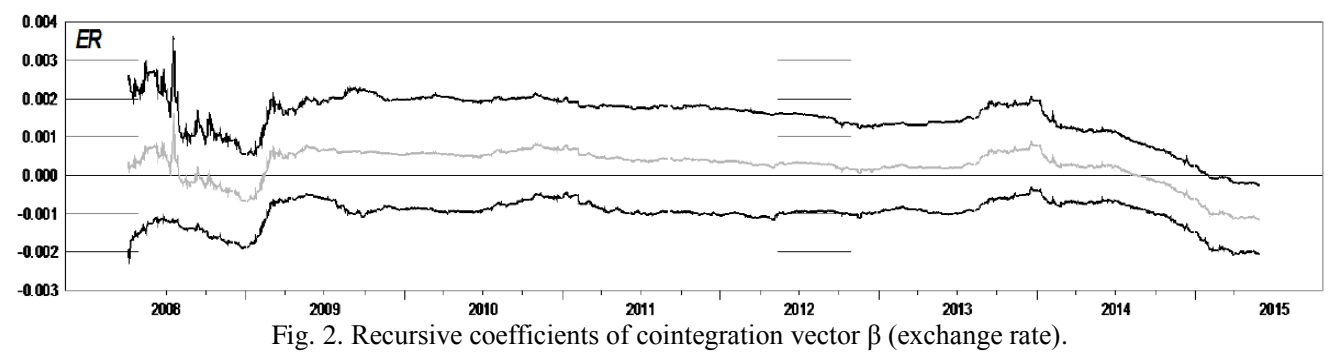

\section{B. Result of the Gregory and Hansen Tests}

TABLE II: RESUlT OF THE GREGORY AND HANSEN COINTEGRATION TEST

\begin{tabular}{|c|c|c|c|}
\hline $\begin{array}{c}\text { Test } \\
\text { Statistic }\end{array}$ & $\mathrm{C}$ & $\mathrm{C} / \mathrm{T}$ & $\mathrm{C} / \mathrm{S}$ \\
\hline \multicolumn{4}{|c|}{ JII } \\
\hline \multirow[t]{2}{*}{$\mathrm{ADF}^{*}$} & $-53.21602 * * *$ & $-53.25786 * * *$ & $-53.47443 * * *$ \\
\hline & $(11 / 19 / 2008)$ & $(9 / 22 / 2011)$ & (3/17/2009) \\
\hline \multirow[t]{2}{*}{$\mathrm{Za}^{*}$} & $-2672.448 * * *$ & $-2676.789 * * *$ & $-2672.056 * * *$ \\
\hline & $(11 / 21 / 2012)$ & $(11 / 21 / 2012)$ & $(11 / 20 / 2012)$ \\
\hline \multirow[t]{2}{*}{$\mathrm{Zt}^{*}$} & $-79.68348 * * *$ & $-79.76259 * * *$ & $-79.94058 * * *$ \\
\hline & $(11 / 19 / 2008)$ & $(11 / 19 / 2008)$ & $(4 / 28 / 2009)$ \\
\hline \multicolumn{4}{|c|}{ JKSE } \\
\hline \multirow[t]{2}{*}{$\mathrm{ADF}^{*}$} & $-27.42403 * * *$ & $-27.49523 * * *$ & $-27.41287 * * *$ \\
\hline & $(10 / 24 / 2013)$ & $(12 / 16 / 2008)$ & $(11 / 05 / 2007)$ \\
\hline \multirow[t]{2}{*}{$\mathrm{Za}^{*}$} & $-2194.112 * * *$ & $-2197.260 * * *$ & $-2196.643 * * *$ \\
\hline & $(10 / 23 / 2013)$ & $(12 / 15 / 2008)$ & $(1 / 15 / 2013)$ \\
\hline \multirow[t]{2}{*}{$\mathrm{Zt}^{*}$} & $-46.30516^{* * *}$ & $-46.35438 * * *$ & $-46.35463 * * *$ \\
\hline & $(10 / 22 / 2013)$ & $(12 / 15 / 2008)$ & $(1 / 15 / 2013)$ \\
\hline
\end{tabular}

Notes: A, B, and C denote model types and correspond to the three models in [6]. The critical values are from Table [6].*** indicates significance at the

$1 \%$ level. The numbers in brackets are estimated structural break dates.

For considering the sample period with some shocks by financial and economic innovations, we employ the $\mathbf{G H}$ cointegration test with structural breaks to examine the long-run relationships among stock, oil, and natural gas prices, and the exchange rate. The results of $\mathrm{GH}$, as Table II, show that all of the modified $\mathrm{ADF}^{*}, \mathrm{Z}_{\alpha}{ }^{*}$, and $\mathrm{Z}_{\mathrm{t}}{ }^{*}$ tests for three different models of both cases, where JII and JKSE are the dependent variable, reject the null hypothesis of no cointegration at the $5 \%$ significant level. This means that there is a long-run cointegrating relationship with a structural break among the four variables. The empirical evidence shows that the main structural break occurred in 2008 and 2009 , and at the end of 2012, which encompass the 2008 global financial crisis and the Euro crisis, respectively. Moreover, in 2008 Indonesia dropped out of OPEC and became oil importer, which led to a decrease in its oil production and an unstable Indonesian economy.

\section{Results of the Recursive Cointegration}

To see the dynamic convergence of the variables in each period, this section uses a recursive cointegration test.

\section{1) Jakarta islamic index (JII) as the dependent variable}

Using JII as the dependent variable, we examine the time-varying convergence of it and the other three variables. Fig. 1, is the result of the recursive trace statistics of JII, exchange rate, and oil and gas prices. After 2009, there is just one line, the upper first line, over the $5 \%$ critical value, which shows that the four non-stationary time series are linked together by one cointegration vector. Thus, this reveals there is a long-run relationship among JII, exchange rate, and oil and gas prices.

The recursive coefficient matrix for the cointegrating vectors, matrix $\beta$ is estimated as Figs. 2, 3, and 4, which is a normalized vector around JII. In Fig. 2, the coefficent's $\beta$ for the exchange rate is positive for much of the whole period, which implies that the depreciation of Indonesia's currency raises stock prices, JII. Comparing the coefficients of oil and gas prices, oil price's coefficient is negative but gas price's coefficient is positive, as in Figs. 3 and 4, implying that rising 
oil prices decrease stock prices, but higher gas prices raise stock prices. Indeed, higher gas prices lead to the greater government revenue from natural gas exports, helping to improve the nation's economic condition. Such improving economic growth helps attract more foreign investments into Indonesia, and then could help raise stock price due to higher expected economic growth.

On the other hand, the share of oil prices to GDP has been declining continuously over the past three decades. Theory suggests that the effect of oil income on the economy's steady-state growth rate will nearly vanish eventually [33]. Oil production fell by $29.64 \%$ from 1.13 million barrels per day in 2004 to 798,000 barrels in 2014. New oil contracts signed dropped from 23 to 7 [32], making it hard for the oil production to meet Indonesia's oil demand, and influencing the stock market.
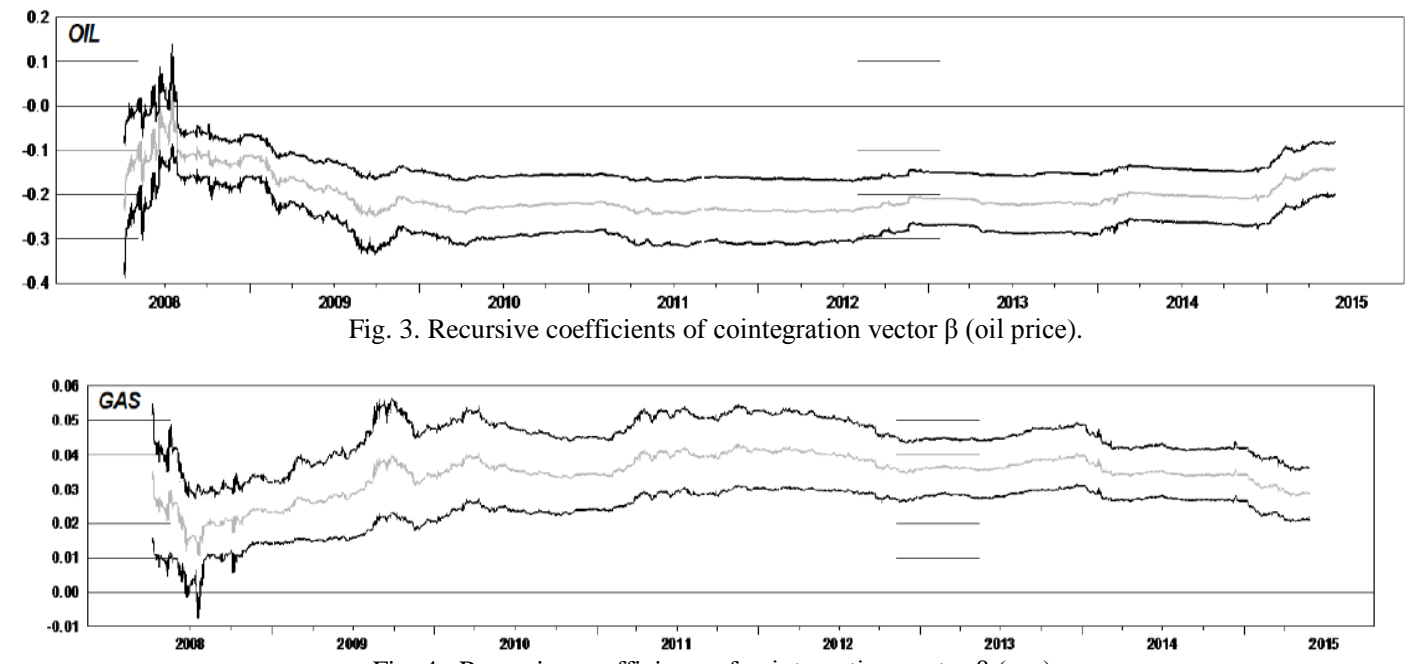

Fig. 4. Recursive coefficients of cointegration vector $\beta$ (gas).

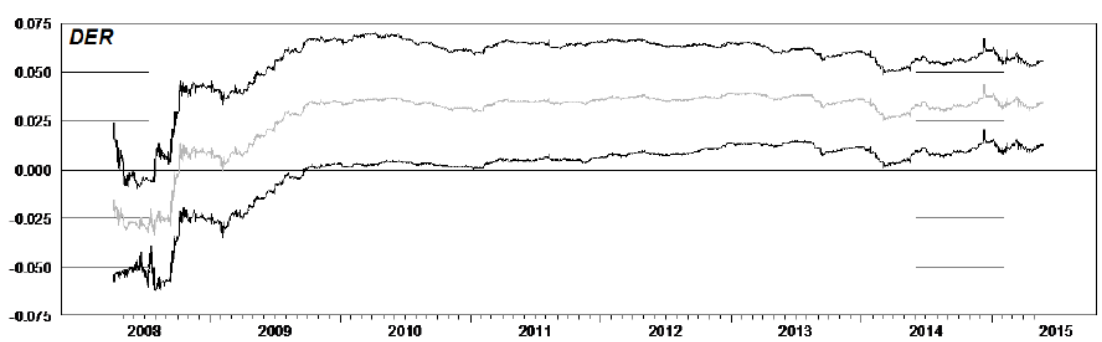

Fig. 5. The Recursive Speed Of Adjustment Coefficients $\alpha$ (exchange rate).

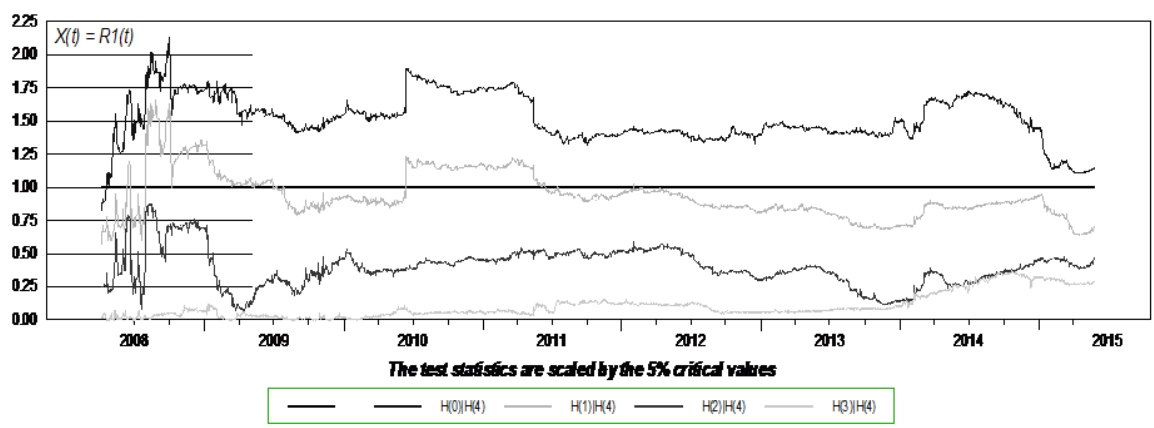

Fig. 6. Recursive trace statistic (JKSE).

We subsequently estimate the recursive coefficient matrix of the error correction terms (matrix $\alpha$ ) for recursive cointegration of the three variables, with the results as Figs. 5, 6 , and 7 . The two coefficients, $\alpha$, of exchange rate and oil price, as Figs. 5 and 6 , are positive, meaning that any deviation of the two variables cannot move back to long-run equilibrium. Conversely, the coefficient, $\alpha$, of gas price is negative, implying that it is a key variable to move the deviation back to the long-run equilibrium. In other words, gas prices play an important role in stabilizing the relationships of the four markets in Indonesian.

While, oil production in Indonesia has fallen over time, caused by natural maturation of its oil fields combined with a slower reserve replacement rate and decreased exploration/investment [32], natural gas production has grown by more than $11 \%$ from 2000 to 2013 and continues to be a major export commodity in Indonesia [8]. Indonesia is the world's fifth-largest exporter of liquid natural gas (LNG) in 2014. Thus, its natural gas market plays an important role in affecting Indonesian stock prices.

2) Jakarta composite stock index (JKSE) as the dependent variable

Fig. 8 is the result of recursive trace statistics of JKSE, exchange rate, and oil and gas prices. Similar to the previous result, there is just one line after 2009 that shows the upper 
first line is over the $5 \%$ critical value. It means that the four non-stationary time series are linked together by one cointegration vector. This figure reveals that there is a long-run relationship among the four variables of, JKSE, exchange rate, and oil, and gas prices.

The recursive coefficient matrix for the cointegrating vectors, matrix $\beta$, is estimated as Figs. 9, 10 and 11, and the cointegrating vector is normalized around JKSE. The result of Fig. 10 shows a positive relationship between the exchange rate and JKSE after 2008, but the recursive coefficient of oil price, as in Fig. 11, is negative after 2008. The recursive coefficient of natural gas price, as in Fig. 12, also is positive for the whole period. This means Figs. 1-7 are similar to Figs. 8-14.
The recursive coefficient matrix of the error correction terms (matrix $\alpha$ ) for the case of using JKSE as the dependent variable is estimated as Figs. 12, 13 and 14. These three figures show similar results to the case of using JII as the dependent variable. The two coefficients, $\alpha$, of exchange rate and oil price are also positive, meaning that any deviation of the two variables cannot move back to the long-run equilibrium. In contrast, the coefficients, $\alpha$ of gas price is negative, implying that it is a key variable to move the deviation back to the long-run equilibrium. The results of these three figures confirm that gas prices play an important role in stabilizing the relationships among the four markets in Indonesia.

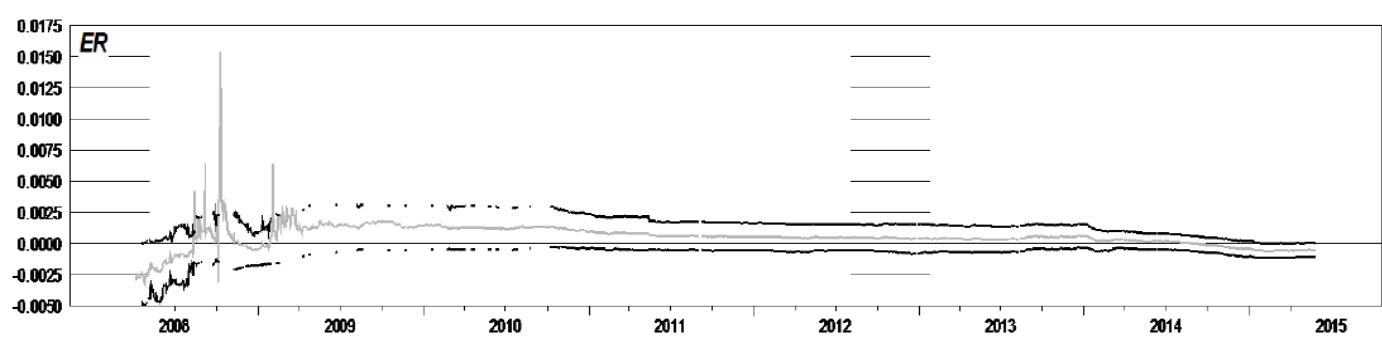

Fig. 9. Recursive coefficients of cointegration vector $\beta$ (exchange rate).

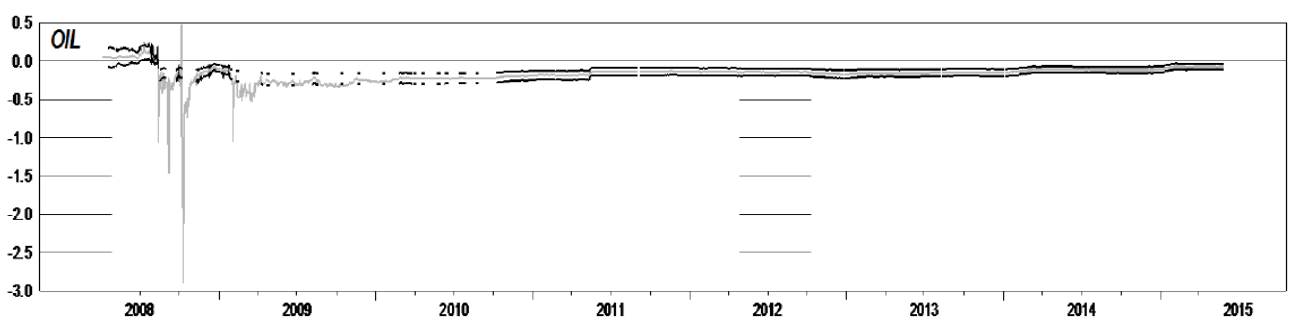

Fig. 10. Recursive coefficients of cointegration vector $\beta$ (oil price).

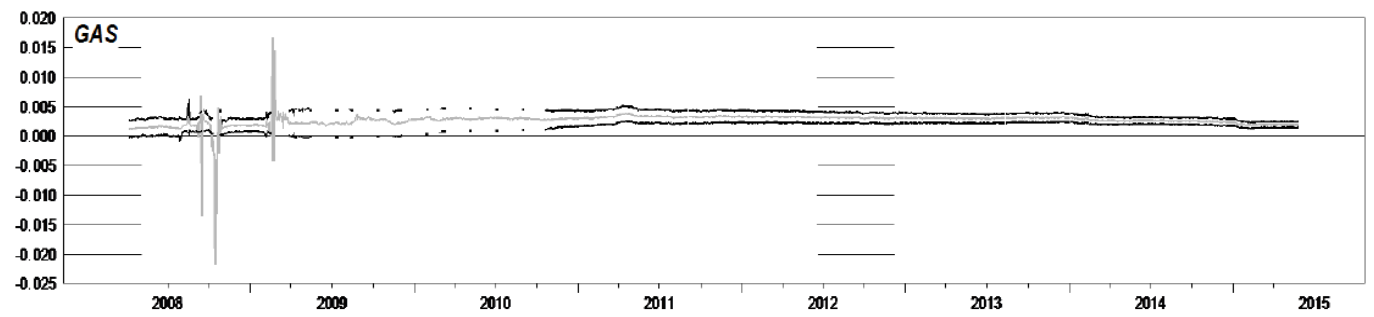

Fig. 11. Recursive coefficients of cointegration vector $\beta$ (gas).

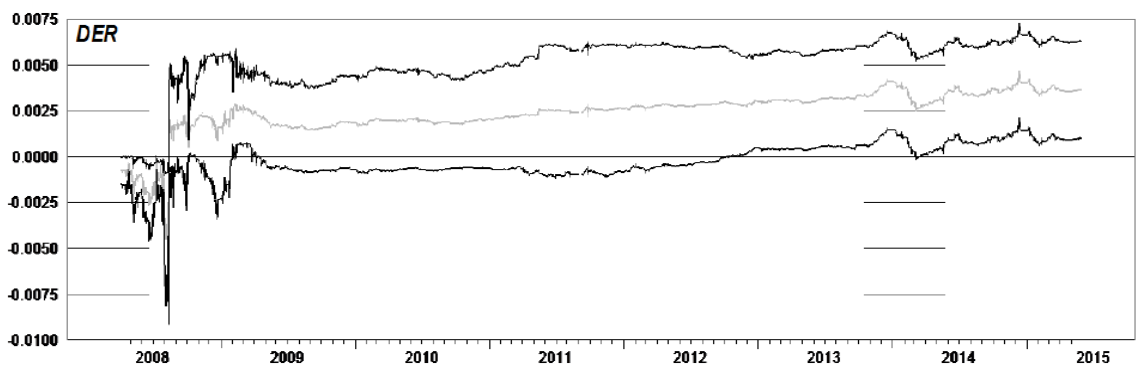

Fig. 12. Recursive speed of adjustment coefficients $\alpha$ (exchange rate).

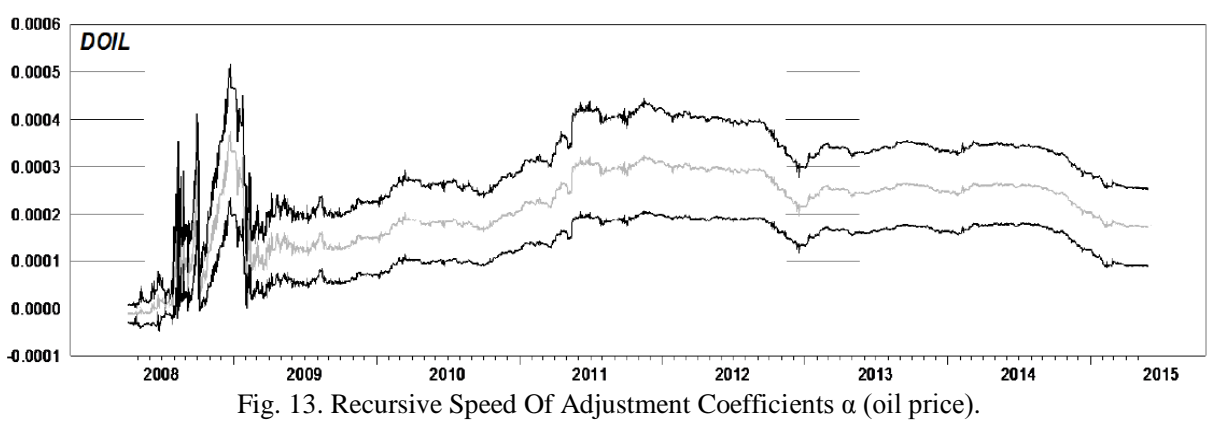




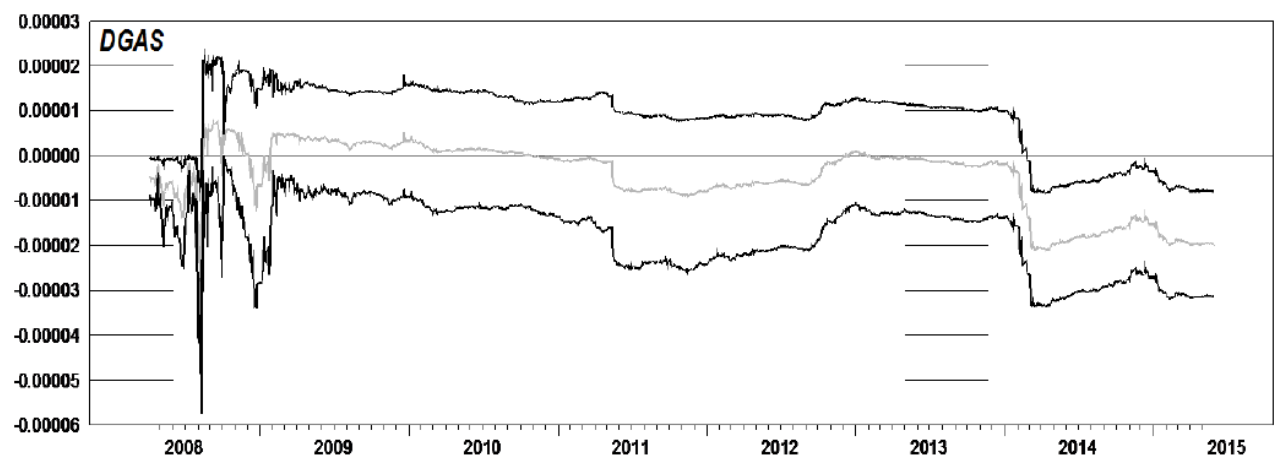

Fig. 14. Recursive speed of adjustment coefficients $\alpha$ (gas price).

\section{CONCLUSION}

This paper investigates the time-varying behavior and the dynamic linkages of Indonesian stock, oil, and natural gas prices over the period from 2005 to 2015. To capture the dynamics of long-run relationships, we use the $\mathrm{GH}$ cointegration test with a structural break and a recursive cointegration test to examine the time-varying nature of convergence here. The main findings are as follows.

First, the result of the GH cointegration test shows that the main structural break occurred in the long-run cointegration around 2008 and 2009, which is naturally caused by the global financial crisis. Second, the results of recursive cointegration show that there is a cointegration among the four variables after 2009.

Third and finally, the results of the recursive cointegration's coefficients display that higher oil prices decrease Indonesian stock prices, but rising gas prices bring about higher Indonesian stock prices. The recursive short-run coefficient of gas price is negative, which implies that it is a key variable to move the deviation back to long-run equilibrium.

\section{ACKNOWLEDGMENT}

The authors would like to acknowledge the Directorate General of Resources for Science, Technology and Higher Education of Indonesia for financial suport.

\section{REFERENCES}

[1] D. W. Jones, P. N. Leiby, and I. K. Paik, "Oil price shocks and the macroeconomy: What has been learned since 1996?" Energy Journal 25 , pp. 1-32, 2003.

[2] J. Cunado, S. Jo, and F. P. D. Gracia, "Macroeconomics impacts of oil price shocks in Asian economies," Energy Policy, vol. 86, pp. 867-879, 2015.

[3] P. K. Narayan and S. Narayan, "Modelling the impact of oil prices on vietnam's stock prices," Applied Energy, vol. 23, pp. 511-532, 2010.

[4] S. Ghost and K. Kanjilal, "Co-movement of international crude oil price and Indian stock market: Evidences from nonlinear cointegration tests," Energy Economics, vol. 2926, pp. 1-7, 2014.

[5] N. Apergis and S. M. Miller, "Do structural oil-market shocks affect stock prices?" Economics Working Paper 51R, 1-26, July 2008.

[6] A. W. Gregory and B. E. Hansen, "Residual-based tests for cointegration in models with regime shifts," Journal of Econometrics, vol. 70, pp. 99-126, 1996.

[7] IDX Statistics Book. (2014). [Online]. Available: http://www.idx.co.id/Portals/0/

[8] U.S. Energy Information Administration. (October 2015). Indonesia International Energy Data Analysis. [Online]. Available: http://www.eia.gov/beta/international/analysis_includes/countries_lon $\mathrm{g} /$ Indonesia/indonesia.pdf
[9] N. F. Chen, R. Roll, and S. A. Ross, "Economic forces and the stock market," Journal of Business, vol. 59, no. 3, pp. 83-403, 1986.

[10] R. Bhar and A. G. Malliaris, "Oil prices and the impact of the financial crisis of 2007-2009," Energy Economics, vol. 33, pp. 1049-1054, 2011.

[11] RSIS. (February 2015). Tumbling Oil Prices: Bittersweet Implications for Indonesia. [Online]. Available: http://www.establishmentpost.com/tumbling-oil-prices-bittersweet-im plications-indonesia/

[12] S. S. Ghoury, "Assessment of the relationship between oil prices and Us oil stocks," Energy Policy, vol. 34, pp. 3327-3333, 2006.

[13] S. Chen, "Do higher oil prices push the stock market into bear territory?" Energy Economics 30, pp. 490-495, 2010.

[14] J. I. Miller and R. A. Ratti, "Crude oil and stock markets: Stability, instability, and bubbles," Energy Economics, vol. 31, pp. 559-568, 2009.

[15] G. Filis, S. Degiannakis, and C. Floros, "Dynamic correlation between stock market and oil prices: The case of oil-importing and oil-exporting countries," International Review of Financial Analysis, vol. 20, pp. 152-164, 2011.

[16] I. El-Sharif, D. Brown, B. Burton, B. Nixon, and A. Russel, "Evidence on the nature and extent of the relationship between oil prices and equity values in the UK," Energy Economics, vol. 27, pp. 819-830, 2005.

[17] L. Dagher and S. E. Hariri, "The impact of global oil price shocks on the Lebanese stock market," Energy, vol. 63, pp. 366-374, 2013.

[18] I. Henriques and P. Sadorsky, "Oil prices and the stock prices of alternative energy companies," Energy Economics, vol. 30, pp. 998-1010, 2008.

[19] J. Park and R. A. Ratti, "Oil price shocks and stock market in the U.S and 13 European countries," Energy Economics, vol. 30, pp. 2587-2608, 2008

[20] S. Mohanty, M. Nandha, and G. Bota, "Oil shocks and stock returns: the case of the Central and Eastern European (CEE) oil and gas sectors," Emerging Market Review, vol. 11, pp. 358-372, 2010.

[21] C. C. Lee and J. H. Zeng, "The impact of oil price shocks on stock market activities: Asymmetric effect with quantile regression," Mathematicsand Computers in Simulation, vol. 81, pp. 1910-1920, 2011.

[22] C. Aloui and R. Jammazi, "The effects of crude oil shocks on stock market shifts behaviour: A regime switching approach," Energy Economics, vol. 31, pp. 789-799, 2009.

[23] E. Papapetrou, "Oil price shocks, stock market, economic activity and employment in Greece," Energy Economics, vol. 23, pp. 511-532, 2001.

[24] T. Angelidis, S. Deggiannakis, and G. Filis, "US stock market regimes and oil prices shocks," Global Finance Journal, vol. 28, pp. 132-146, 2015.

[25] H. M. Zhu, R. Li, and S. F. Li, "Modelling dynamics dependence between crude oil prices and Asia-Pacific stock market returns," International Review of Economics and Finance, vol. 29, pp. 208-223, 2014.

[26] S. F. Li, H. M. Zhu, and K. Yu, "Oil prices and stock market in China: A sector analysis using panel cointegration with multiple breaks," Energy Economics, vol. 34, pp. 1951-1958, 2012.

[27] P. Adam, U. Rianse, E. Cahyono, and M. Rahim, "Modeling of the dynamics relationship between world crude oil prices and the stock market in Indonesia," International Journal of Energy Economics and Policy, vol. 5, pp. 550-557, 2015.

[28] N. A. Fahami, S. Haris, and H. A. Mutalib, "An econometric analysis between commodities and financial variables: The case of Southeast 
Asia countries," International Journal of Business and Social Science, pp. 216-223, vol. 5, no. 7, 2014.

[29] H. Robiyanto, S. Wahyudi, and H. Muharam, "The world oil price movements and stock returns in several Southeast Asia's Capital Markets," IJABER, vol. 13, no. 2, pp. 527-534, 2015.

[30] G. Elliot, T. J. Rothenberg, and J. H. Stock, "Efficient tests for an autoregressive unit root," Econometrica , vol. 64, no.4, pp 813-836, 1996.

[31] E. Zivot and D. W. K. Andrews, "Efficient tests for an autoregressive unit root," Journal of Business and Economic Statistics, vol. 10, no. 3, pp. 251-270, 1992

[32] PWC, Oil and Gas in Indonesia investment and Taxation Guide, May 2014.
[33] H. S. Eshafani, K. Mohaddes, and M. H. Pesaran, "An empirical growth model for major oil exporters," CESIFO Working Paper, pp. 1-25, March 2012

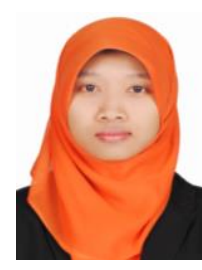

Nur Setyowati is Indonesian, who was born in January 1992. She possesses a BSc in sharia banking from State Polytechnic Semarang, Indonesia in 2014. She is presently finishing her MSc of finance in Nationa Kaohsiung University of Applied Sciences, Taiwan. She is interested in vast area of stock market, energy policy, banking, monetary policy, corporate finance and international finance. 